\title{
Study on Modes of Cultivation of Innovative Entrepreneurship Talents
}

\author{
Yurong Chen \\ School of Economics \& Management, Changzhou University \\ Changzhou 213164, Jiangsu, China \\ E-mail: cyrpzh@126.com
}

Foundation item: "Jiangsu College and University Innovative and Entrepreneurship Talent Training Research (ZZKT09198)" of Jiangsu Province Higher Education Association Project Subject and "Chang Zhou Science and Education Park College and University Innovative and Entrepreneurship Talent Training Research (K2009202) of Chang Zhou Science and Education Park College and University Scientific Research Foundation Item Project.

\begin{abstract}
Starting from demand on innovative entrepreneurship talents by the economy and the society, this article will make a systematic design and practice on modes of cultivation of innovative and entrepreneurship talents, including changing educational idea, optimizing cultivation goal and mode, innovating teaching methods, strengthening practical education and the second class, reforming assessment means, optimizing the structure of teachers and setting up guarantee system.
\end{abstract}

Keywords: Colleges and universities, Innovative entrepreneurship, Cultivation of talents

Colleges and universities are the base of cultivation for innovative entrepreneurship talents, and are also the breeding ground for the thought of innovative entrepreneurship. Besides, they are the important subject of innovation system of the nation, so innovation of education will directly influence the innovative strength of the country. Therefore, with transformation of the times, study on modes of cultivation of innovative entrepreneurship talents is an important and urgent task for colleges and universities.

1. To change the educational idea and to realize education of integration of innovation and entrepreneurship

Innovation and entrepreneurship are a dialectical unity. Innovation focuses on discovery of value, whereas entrepreneurship focuses on fulfillment of the value. Innovation and entrepreneurship has a necessary connection in that, innovation is the premise and foundation of entrepreneurship activities, is the central factor and essential characteristics of entrepreneurship activities, is the soul and key of entrepreneurship and is also sustainable guarantee of entrepreneurship. Thus, entrepreneurship is based on innovation and pushes forward innovation.

Innovation and entrepreneurship are mutually integrated, mutually supplemented, mutually promoting and mutually restricting. Innovation education refers to educational activities that regard cultivation of such innovative factors as innovative awareness, innovative spirit, innovative thinking and innovative competence and innovative talents, which concentrates on the overall development of human being, is the fundamental requirement for each student and is a kind of popularized education. Entrepreneurship education refers to educational activities that develop and improve the basic quality of entrepreneurship, cultivate entrepreneurship awareness and spirit, formulate initial entrepreneurship competence and grasp basic skills of entrepreneurship, which concentrates on fulfillment of the self-value of human being. Innovation and entrepreneurship have their internal necessary connection, which also enables innovative education and entrepreneurship education to have the necessity of internal connection. Thus, cultivation of talents of "both innovation and entrepreneurship" should realize integration of innovative education and entrepreneurship education.

2. To optimize cultivation goal and to make clear the goal orientation of talents of "both innovation and entrepreneurship"

The characteristics of the target of talents of "both innovation and entrepreneurship" include, on one hand, common characteristics of talents of "both innovation and entrepreneurship", and, on the other hand, professional characteristics of professional talents. Talents of "both innovation and entrepreneurship" should have solid knowledge substrate and relatively complete knowledge structure, perfect habits and capacity of 
independent learning and re-learning, typical innovation and entrepreneurship consciousness and fortitudinous spirit and will, acute insight and original thinking way, able to judge and grasp opportunities, superb innovation capacity and ability of practice, implementation and expansion, excellent team spirit, cooperative ability and social competitive force. For the second kind of characteristics of talents of "both innovation and entrepreneurship", we take talents of economic management talents as an example. Economic management means that in economic activities, people conduct rational organization and effective allocation on such elements and resources as human resources, financial resources, material resources and technique, etc, so as to achieve effective operation and effective output of economic activities, which not only involves control over human and matters, but also involves management of finance and things. Thus talents of "both innovation and entrepreneurship" in the field of economic management should have the ability of institutional innovation, management innovation, organizational innovation and service innovation on the basis of "understanding management and good at management", and should grasp opportunities to realize potential value of innovative achievements.

\section{To optimize cultivation modes and to establish and make sound cultivation mechanism of talents of "both innovation and entrepreneurship"}

3.1 We should positively explore modes of cultivation of diversified talents according to requirement of development of market economy, especially demand of local economic and social development on diversified and multi-level talents and due to difference of demands by different personalities of students on education.

3.2 We should strengthen the mechanism of students' independent learning and the mechanism of students' self-development. Schools should respect choice, interests and favor of students, enlarge students' autonomous right of learning and cultivate students' independent learning consciousness and independent learning ability. They should improve the flexible educational system, cultivate and teach at different levels and expand the space of students to independently select their majors, independently choose their teachers, and independently select their courses.

3.3 To optimize the project of cultivation of talents. Firstly, universities should reinforce the general education and lay a solid foundation; secondly, universities should broaden the profile of specialties, and strengthen adaptability of profession; thirdly, universities should add courses of interdisciplinary subjects, cultivate the knowledge structure of students' multiple subjects and improve human details and scientific quality; fourthly, universities should bring in teaching content and course system of developed countries and expand students' international vision; fifthly, universities should follow up with the leading edge of subject development and keep up with scientific development and economic and social development; sixthly, universities should set up innovation and entrepreneurship educational module or system, and conduct innovation and entrepreneurship education pertinently; seventhly, universities should further improve practical teaching system and strengthen practical teaching.

\section{To innovate teaching methods and improve the educational and teaching mode in which teachers play the leading role and students are the subject}

4.1 To strengthen training of students' consciousness of problems and training of thinking ability. The process of learning is more important than the result of learning. In the process of learning, students' initiative should be fully played. Knowledge has its sociality, and is implied in a team or community, and more cooperation and conversational method is helpful for improvement of learning. Thus, universities should abandon the traditional course teaching method which regards impartation as the major content and which merely adapts to knowledge impartation, and carry out positively problem teaching method and exploration teaching method. In this way, classes in which teachers play a leading role will become an occasion that teachers and students discuss together, teachers become the facilitator and cooperator of students in their learning. Universities ought to concentrate on the generation process of knowledge, train students' independent thinking ability, activate students' innovative thinking and intensify training of students' problem consciousness and cultivation of their innovative ability.

4.2 To emphasize connection of theory and practice. Firstly, universities should vigorously carry out the case method of instruction. Students discuss a series of practically existing cases, put forward a resolution to resolve problems and enable students to grasp relative professional skills, knowledge and theory; secondly, universities should widely employ the teaching method of simulation, and ask students to use a simulator or simulation context to play a certain role under the circumstance when they get approach to a realistic situation, and interact with a certain person or matter, so as to achieve the anticipated learning purpose and cultivate students' ability of information acquisition, action skills and decision making, etc; thirdly, universities should popularize and carry out the teaching method of "actual combat", and ask students to play a certain real role in a realistic situation in a 
real social environment and working environment, conduct business work, so as to achieve the real learning purpose, including course design, course investigation, course internship, and course practice, etc.

\section{To strengthen practical education and set up the practical teaching mode which integrates on-campus simulation and off-campus practice into one whole}

5.1 To construct in a systematic way the practical teaching system which is established in cultivation of capacity. Universities should realize the entire optimization of practical teaching content system so as to establish the practical teaching system in which the four aspects of course practice, investigation internship, dissertation design and off-campus practice are the focus, which regards the four progressive ladders of public practice, subject practice, professional practice and comprehensive practice as the level, which insists on the continuous four years of practical teaching and which runs through the whole learning process of the phase of undergraduate education.

5.2 To continuously upgrade and optimize the content of practical teaching and to continuously update and optimize the content of practical teaching according to the situation of social development of progress of scientific technique. Universities should design the outline of experimental teaching in a scientific way, reduce demonstrative and replication experiment content, add comprehensive, designed, open and innovative experimental content, and ensure that students get sufficient basic skills and innovative capacity training in experimental teaching; universities should continuously enlarge students' independent experiment, let them independently select an experimental direction, independently finish an experimental design under the direction of teachers, and independently confirm experimental content, method and procedure and finish the entire process of the experiment, so as to strengthen students' ability to conduct innovative experiment.

5.3 To strengthen the scientific training in which graduation project (thesis) is the central content. In order to ensure and improve quality of graduation project (thesis), universities should make the subject selection, application and appraisal system strict, definitely require that a subject selected should be closely combined with the scientific research subject, production practice and social work of tutors, improve the rate of updating of selection of graduation project (thesis), and guarantee the advancement and innovation of a subject selected.

5.4 To strengthen construction of on-campus simulation practice base. Universities should set up integrated, designed and comprehensive practical teaching platform and simulation and practice base for students' on-campus innovation and entrepreneurship internship. Universities should give full play to advantages of on-campus teaching practice in teaching method, teaching mode and teaching means, etc, take an initiative in reform of practical teaching and reinforce students' practical ability and innovative ability training.

5.5 To strengthen combination with the society, production and scientific research. Universities should explore a new mode of cooperation among school enterprises, and enable students to play a real role in a real environment and conduct real and practical teaching activities. According to the thought of integrated construction of students' internship, employment and entrepreneurship base, universities should set up a strategic cooperation relationship with enterprises, especially privately owned enterprises, gradually expand the vigor and depth of cooperation and create more opportunities for students to combine with the society, production and scientific research.

\section{To strengthen the second classroom and construct the second channel for cultivation of talents of "both innovation and entrepreneurship"}

6.1 Universities should hold activities of "forum of innovation and entrepreneurship" and stimulate consciousness and impulse of "both innovation and entrepreneurship". On-campus and off-campus educational resources should be employed to organize for students high quality "innovation and entrepreneurship report", "forum of innovation and entrepreneurship", "classroom of entrepreneurs" and "reporting meeting about successful entrepreneurship of successful schoolfellows", and universities should refer to rich knowledge, original opinions and successful entrepreneurship process of experts, professors and entrepreneurs to stimulate and encourage students and intensify students' confidence and decision of innovation and entrepreneurship.

6.2 Universities should set up scientific management system for university students. They should enlarge investment of funds and encourage students to conduct scientific research and publish high quality academic thesis; encourage teachers to absorb undergraduates to participate in theme research; support construction of academic associations of students, make full use of academic advantages of colleges and departments to development academic associations and encourage students to start academic publications.

6.3 Universities should promote scientific competition among university students by regarding competition of subjects as the carrier. They may hold rich off-campus competitive activities for students to let students participate in scientific research and production as early and as many as possible and increase the opportunities 
for them to cultivate their ability of practice and innovative spirit. In the mean while, by regarding the entrepreneurship plan contest of challenge glass" among university students as the carrier, colleges and universities can combine students' association activities to conduct entrepreneurship contest and simulation entrepreneurship practice, exhibit students' entrepreneurship achievements in a collective way, evaluate students' entrepreneurship ability in a scientific way, help students absorb risk investment, introduce relatively mature entrepreneurship team and entrepreneurship project at an appropriate time and successfully complete students' transform of entrepreneurship from the school to the society.

6.4 Through such organizations as students' "class organization", "association organization", "part-work and part-study service center" and "entrepreneurship center of students", universities can pertinently conduct such activities as "psychological training", "entrepreneurship discussion" and "entrepreneurship simulation" to train the psychological quality of those who initiate an enterprise.

6.5 Universities should take an initiative to hold on-campus "entrepreneurship practice" activities and train the ability of entrepreneurship practice. They should integrate on-campus teaching resources, start open laboratories or innovative laboratories for students' innovation and entrepreneurship, fully excavate and explore on-campus entrepreneurship market by referring to students' entrepreneurship content and project, operate association activities in a marketization way and operate social practices and part-work and part-study activities of students in a project way and regard them as the practical carrier of on-campus entrepreneurship of students.

\section{To reform evaluation means and to set up scientific evaluation standard system of the quality of talents} of "both innovation and entrepreneurship"

7.1 Universities should establish scientific evaluation value and correct their knowledge in evaluation target. The evaluation ought to emphasize the comprehensive and harmonious development of the overall quality of human being, and not only grasp of knowledge of students should be evaluated, but also the comprehensive ability of quality of students should also be evaluated. Universities can improve students' knowledge use ability, self-learning ability, ability to analyze and resolve problems, self-evaluation ability and the ability of evaluate others, and the psychological quality and coordination spirit through the leading role of evaluation.

7.2 To reform course evaluation content and means, and to confirm the exam content and evaluation standard which regards the test ability, quality and innovative factors as the subject. The evaluation content and evaluation standard which lays special emphasis on evaluation of knowledge memory should be changed to test on students' ability, quality and innovative factors, and the content of evaluation should be with challenges and competitiveness and should stimulate the innovative consciousness, innovative desire and innovative enthusiasm of students and should encourage students to spare no effort to conduct discussion and exploration. In terms of evaluation standard, innovative factors should be regarded as the major evaluation index. An open and flexible exam means should be used and the evaluations means should be established in which the major means include open-book evaluation, disperse evaluation and process evaluation.

7.3 Universities should improve the comprehensive evaluation methods of students and bring the spirit and ability of "both innovation and entrepreneurship" into the evaluation index system. In order to regard embodiment of students' cultivation target as the direction of students' daily behavior, universities should use scientific, fair, rational and comprehensive evaluation standard to make a quantitative and overall evaluation on the condition of students' moral, intellectual, physical and aesthetical development aspects, encourage those who advance and give an impetus to those laggers, improve students' overall quality and promote students' comprehensive development in the moral, intellectual, physical and aesthetic development. In order to further strengthen the direction of the target, and lead students in their independent learning and research learning, universities should reinforce cultivation of talents with the consciousness and ability of "innovation and entrepreneurship" to play the correct and effective role of "a directing stick", supplement and improve factors in "innovation and entrepreneurship" in students" quantitative and overall evaluation system, supplement test on the consciousness and spirit of "innovation and entrepreneurship" in test of moral education and supplement test on ability of "innovation and entrepreneurship" in evaluation of intellectual education.

\section{To optimize teachership structure and set up through internal cultivation and external introduction a team of teachers of "both innovation and entrepreneurship" which regards profession as the major and which has the combination of profession and part-time}

8.1 Universities should carry out the project of cultivation of talents and improve the quality of the team of teachers. They should strengthen vigor on cultivation of young middle-age teachers, further optimize the structure of the team of teachers, gradually form advantages of the group of "three highs and one low", namely, high educational degree, high title and high level and low age, give full play to the role of imparting, assisting 
and leading of excellent teachers, and improve the teaching skill and professional level of young teachers through multiple channels and multiple approaches. In the mean time, universities should take an initiative to conduct training of entrepreneurship education among teachers, invite entrepreneurship education experts to set up classes of entrepreneurship of a short period of time and to impart entrepreneurship theory and knowledge, skills and entrepreneurship education method and encourage teachers to do social practice or take a temporary post for practice in public organs and institutions, and especially some teachers who teach practical classes.

8.2 Universities should strengthen vigor of introduction of excellent talents and realize diversification of the team of teachers. They should take particular policies to bring in domestically well-known high level professional foregoers in a subject and leading talents in academic establishment, actively bring in academic professional foregoers with advanced international educational background, try to form an academic team which corresponds with demand of school positioning and academic professional construction and improve the overall scientific innovation ability of the school. They should reinforce cooperation with entrepreneurs, fully absorb and employ social entrepreneurship resources, especially teachers in the subject of economic management, invite successful entrepreneurship personnel, entrepreneurs, vocational managers, investment experts and management experts to take part-time professors in the school, or irregularly give a speech or a lecture to diversify the team of teachers of "both innovation and entrepreneurship".

9. To set up a guarantee mechanism and improve the organizational and management system of cultivation of talents of "both innovation and entrepreneurship"

Cultivation of talents of "both innovation and entrepreneurship" is a systematic project, which needs attention of leaders at all levels of the school and support and cooperation of all departments, especially the teaching units and departments at all levels which are the subjects of teaching. The cultivation function of talents of "both innovation and entrepreneurship" should be fully tapped and the spirit of innovation and the courage to put into action should be tapped to set up and improve the guarantee mechanism of cultivation of talents of "both innovation and entrepreneurship". Universities should make perfect the organizational institutions, set up leading groups for innovation and entrepreneurship education of university students and innovation and entrepreneurship guidance centers, take responsibility for entrepreneurship education of all university students, strengthen organization, coordination and management of the education of "innovation and entrepreneurship", improve rules and regulations, formulate directive opinions for innovation and entrepreneurship education of university students, bring education of "both innovation and entrepreneurship" into standardized and institutional management, establish special funds of "both innovation and entrepreneurship" and provide special financial assistance for activities of "both innovation and entrepreneurship" of university students.

\section{References}

Cao, Shengli. (2008). Construction of Innovative Countries and Cultivation of Innovative Entrepreneurship Talents. China Higher Education Research, (5).

Liu, Lijun. (2009). Science Entrepreneurship Education in First-class Universities in US and Cultivation of Innovation and Entrepreneurship Talents in China. China Higher Education Research, (5).

Sun, Xiaomei. (2010). Discussion on Functions of Entrepreneurship Base of University Students and Cultivation of Innovative Entrepreneurship Talents. Heilongjiang Higher Education Research, (1).

Xu, Hui. (2009). Evaluation Standard of Cultivation of Innovation and Entrepreneurship Talents in Colleges and Universities. Jiangsu Higher Education, (6).

Ye, Peiliang. (2010). Rational Thought on Innovation and Entrepreneurship Education among University Students. Education and Vocation, (3).

Zhang, Hongbao. (2006). Brief Discussion on Cultivation of Innovation Spirit and Entrepreneurship Ability of University Students. China Higher Education, (24). 